\title{
Define the Relation between War and Cultural Invasion and Target Groups
}

\author{
Golamreza Alamati ${ }^{1}$ \\ ${ }^{1}$ University of Imam Hussein (AS), Tehran, Iran \\ Correspondence: Golamreza Alamati, University of Imam Hussein (AS), Tehran, Iran.
}

Received: May 15, 2016 Accepted: June 6, 2016 Online Published: June 29, 2016

doi:10.5539/jpl.v9n5p209 URL: http://dx.doi.org/10.5539/jpl.v9n5p209

\begin{abstract}
The main purpose of this paper explores the phenomenon of war, properties, fields, and triggers this phenomenon well. War as the independent variable and the dependent variable to cultural invasion and target groups respectively. In this paper, the effects of cultural invasion, cultural characteristics of the areas affected by the attacker and target groups, especially young people tries to three dimensions variable studied and soft war, cultural invasion, the target group extensively described and we clearly states its different aspects. The main focus topics, the soft war that despite hard war that targets the human bodies tried to conquer the mind and soul. The values will change. Have changed their culture and native and invasive culture is dominant in various aspects of society.
\end{abstract}

Keywords: soft war, conflict, cultural invasion, soft power of target groups

\section{Introduction}

Dimensions and implications and consequences is very complex and complicated that only by understanding and deep insight that we can deal with it. The destructive power of this new conflict the "soft war" is called. Very daunting and complex. In this study investigates the cultural aspects and consequences, especially on the younger generation and our target groups. The main research question is the fact that the relationship between war and cultural invasion on how target groups. To consider and test these questions and variables we will discuss it at the end of the final result.

\section{Examine Implications}

\subsection{War}

Historically and at the time of the origin and history of war in the 1970s, at the height of the Cold War, a committee entitled "Risk Committee this year by a group of US senators, senior State Department officials, prominent political science professors, Amrklyn Enterprise Research Institute and a group of Site senior CIA and Pentagon was established. The purpose of the establishment of the committee was out of the stalemate between the superpowers during the Cold War when the United States and the Soviet Union there was a nuclear balance. The members of the committee avoided knowing the conflict between the circles of power, the only way out Bhzanv rivals in war and disintegration of the designed and implemented. Solutions "The doctrine of containment, fighting media and organizing civil disobedience" as a war strategy in this period was introduced by the committee. (NYe, 1390: p 7-6).

To explain the soft war, "soft power" to have to explain and explain. Joseph Nye describes soft power, it kind of potential and capacity in attracting and persuading others calls for cooperation and assistance. The most important elements of soft power factors, values, ideas, norms, ideologies, moral and political institutions and culture is considered (Nye, 1990: 153-154).

Soft power on the formation emphasizes their preference and awareness actors and activists without self-consciousness.is. In this situation no physical coercion, and violence is not encouraged and bribed (Nye, 1389, p 281-277 AND Lukes, 1975, p 24)

Soft power is neither force nor money is invested in the soft power of subjectivity. In this kind of charm to share power between the value and the necessity of cooperation in order to achieve the advantage powers (Bvlvrvy http://noorportal.net). 
Use violent threats. If the culture and ideology of the dominant actors have charm others with enthusiasm and tremendous speed of movement and even thought to be the dominant power in question (Security Study Group, 1387, p. 44).

The power diagram, grammatical behavior and selection in a process chain (the threat to economic incentives and then setting the agenda and eventually absorbed are. (Nye, 2004, p 28).

The war can be defined as "soft power to shape the beliefs, values, thoughts, perceptions, expectations, preferences, choices and individual and collective behavior patterns in order to accommodate, adjust, control and change the subject identity human and intellectual world in ensuring the realization of the goals and desired results "(peasant went on, 1390, p 7).

The definition of funds, levels and stages and will cover tools and the nature of war.

\subsection{Points of Difference between the Soft and Soft War}

1) While the software is essentially intangible and tangible threat (hard hreat), essentially revealing and provocative element is lacking.

2) approach in the field of software security threats, including values and social identities but battle-hardened security is the most important external threat.

3) soft threats is the elite product complex thinking and deep understanding of scales, it is very difficult to measure and hard threats because while tangible and concrete measure will have the ability.

4) soft threats within the categories of political, cultural and economic. But basically military and security threats are hard.

5) The security approach is synonymous with decay and dissolution results hard threat opposition or opposition political-security systems to new security threats, while a program is synonymous with the institution-building within the framework of liberal democratic systems of thought and behavior(Seraje, 1388, pp 15-13).

\subsection{War Ends in a Macro View}

In examining the different objectives of the program special attention to the ends it is very necessary.

In a general look soft war goals on a regular basis and regress as follows:

\section{(A) A change in society's beliefs:}

The purpose of war is a breach of fundamental social beliefs.

\section{(B) Changes in ideas:}

Certainly the social beliefs, shaking the foundations of thought and ideas of the community.

\section{(C) Changes in behavior:}

Each model and meme originated from an intellectual background. If it hdshhpzyr intellectual foundation for the emergence of new patterns of behavior inevitably will.

\section{(D) Changes in political structures:}

\subsection{The Objectives of the War in a Micro View}

1) The cultural transformation aimed at influencing heavily on public opinion.

2) The political transformation pretending to inefficient targeting system.

3) Intimidation of issues like poverty, war or external power.

4) Creating discord among the people and sow discord among the political authorities aim.

5) Open and hopelessness in the target population.

6) Injection indifference to the younger generation and macro issues important to the community.

7) Black propaganda to strengthen the popular discontent towards religious differences, ethnic, political and social unrest and overthrow goal.

\section{The Use of Culture in the Process of Soft War Tactics}

The principles of war are rooted in the culture and nature of its cultural programs derived from culture and is based on some of our physiology:

(A) Cultural focalization: Elements such as values, patterns, beliefs, norms, the soft power of a system of 
interrelated networks are considered invasive These elements and facing them within the country forward and create a focal dense cultural elements first of soft war strategy and development of its unique tactics.

\section{(B) Produced universal cultural elements:}

Soft war tactics in the second stage pretending it is obvious that the values and norms and behavioral patterns Country attacker universal, general and applied to the entire humanity the results of such business process integrity, authenticity and validity of these criteria.

\section{(C) Cultural hegemony:}

are undisputed.

\section{(D) Establish absolute truth and virtue:}

Following last stages striker culture based on truth and virtue Fact design abilities. Its cultural elements of absolute truth and the ultimate effects, criteria and behavior patterns and compare them to determine. All aspects of life have been built and put into a form of welfare, safety and happiness of mankind's claim (Held and Mac grew, 2001).

\section{(E) Human responsibility and mission:}

Culture aggressive tactics in line with their cultural and human problems as the issues of the responsibility, freedom, democracy, economy and politics promises superior to humanity.

\section{(F) Cultural process of:}

The creation of meaning and symbolism of the functions of culture in general. Make sense of the world is in the process of cultural reproduction. the target group is targeting community.

In this process, the concept of war appears and works and their angles and target groups in society builds charts. The concept of cultural invasion, cultural invasion mirrored soft war era. With regard to the former pleadings now consider the issue of cultural invasion.

\section{Analysis of the Concept of Cultural Invasion}

\section{(A) culture:}

"Culture is a set of knowledge (cognitive) behavior and technical, economic, rituals (rites), religious, social, specifies that certain human society." (Panvf, 1368, p 103).

Material and spiritual culture can be classified into two levels; the material culture of all that concrete, such as works of art, industrial products, monuments, line, music, and culture and spiritual or immaterial also the beliefs and customs, science and education, values and ideas, morals, knowledge and. (Rousseau, 1369, p 10).

\section{(B) Cultural characteristics:}

Basically, culture with the foregoing definition, features and characteristics are as follows:

1) Is acquired.

2) Is dynamic.

3) Secondary nature of man.

4) Is comprehensive.

5) Edentifying the element.

6) Is relative.

7) There portability.

8) Certain human characteristics and properties is visible only in human societies (Rouhol amini, 1372, p 24-19; Fayyazi, 1372).

\section{(C) Cultural invasion:}

Replace foreign culture with their own culture in a way that is clear and obvious Western scientists themselves admit it. atvklayn leaves one Western psychologists in this regard says:

"Even during the implementation of programs, generous and tolerant, they also contribute to technical cooperation and other forms of exploitation of the colonial attitude is reflected another example, a country that provides technical assistance to that country is expected to help the owner, criteria, and patterns of him adopt. "(Rouhol amini, 1372, p 15). 
Michel Panvf in "sociology of culture" says: recessive) are described. In the past, industrial society genocide by pretending that the purpose of cloning is to create "peace" or "deformation" in primitive societies or backward run and run again. This operation is usually known as ethics, attaining perfection in progress and will be done. "(Panvf, 1368, p 137).

force and replace the national culture and beliefs of people are entering the country (the Islamic Revolution cultural documents, 1373, p 3).

Cecil Rhodes, one of the English thinkers "For the 40 million population of the United Kingdom from a bloody civil war to save Great Britain must acquire new lands to settle the surplus population problem and provide new markets for manufactured goods. As I have always said: "Empire" is a solution to the problem of bread and unemployed civil war if you do not have to be imperialist. "(Rafiee, 1373, p 115).

\section{(D) The characteristics of cultural invasion:}

Essentially "cultural invasion" in the military invasion or economic features is unique. Cultural invasion is invisible and intangible, long-term and Dyrpast, radical and profound, comprehensive and deliberate and has extensive programs and utilities, comprehensive and effective and danger In addition, cultural invasion, a slow process and approach, and its victims are mostly young people.

The feud in the offensive weapon to impose the culture of all political, economic, military, psychological and promotional use (Hdayt khvah, 1377).

\section{(F) The combination of soft War objectives and cultural invasion from the perspective of the Islamic} Republic of Iran

- Disbelief behdin a new generation of revolutionary principles.

- bringing the younger generation of vulgarity and immorality.

- undermine the Islamic and national culture.

- divert young believers from fanatical adherence to their faith and values.

- change the minds of the people of Islam and Islamic thought.

- Replace alien culture and Islamic culture.

- targeting the pure Islamic culture which is the basis and foundation of the Islamic Revolution.

- weaken the resolve of the young in the way of construction.

- weaken the revolutionary spirit and passion of youth.

- Empty the Islamic revolution and religious content.

- Transformation in the government of Shi'ite thought and unable to show the community.

\section{Conclusions}

\subsection{Against Cultural Invasion and War: The Threat Is Considered Soft (Saddle, 1388, p 15-13)}

Cultural invasion and war are actually two distinct and separate from each other, but process but its ratio to each other in such a way that cultural invasion, cultural institutions, the targeted value. But the war in addition to the political foundations, legal structures, principles of legitimacy and political socialization was also attacked. The relationship people have with the political system to make a break. Producer legitimacy and destroyed the foundations of communication between the state and the nation, or at least weakens. Processes of political participation is weak and shaky.

In war, the foundations of political thought are inefficient and artificially appears, served to undermine political beliefs and political officials doubt arises service. The United Nations ranks as a result of religious and ideological links is at risk of collapse.

It is pervasive and widespread apathy in the society, nation and state have been turned away from each other, and mutual trust of each other away. In the process of soft war, what the community is more prevalent in the drvghlibel and slander and tabloids.

Although the invasion of cultural, social cohesion and software in order to disrupt enemy resistance and long-term future, but the software, hardware, such as the relationship between nation-states threatening legal construction of credibility pockets.

In war, the foundations of political thought are inefficient and artificially appears, and served to undermine political beliefs and political officials doubt arises service. The United Nations ranks as a result of religious and 
ideological links is at risk of collapse.

It is pervasive and widespread apathy in the society, nation and state have been turned away from each other, and mutual trust of each other away. In the process of soft war, what the community is more prevalent in the drvghlibel and slander and is Tabloids.

Although the invasion of cultural, social cohesion and software in order to disrupt enemy resistance and long-term future, but the software, hardware, such as the relationship between nation-states threatening legal construction of credibility pockets.

\subsection{Recommendations}

- Religious and spiritual values and divine periodically and according to its needs at different times to be re-educated young people.

- Scientific and ethical patterns in society and cultural measures undertaken in order to identify them.

- Social living conditions of young people and their material needs will be provided, which complement previous measures.

- Youth character recognition is frequently used in various ceremonies.

\section{References}

Fayyad, M. S. (1372). Introduction to the West's cultural invasion, the Center for Islamic Studies. Tehran, of the Ministry of Culture and Islamic Guidance.

Harrison, N. (2003). Post Colonial Criticism. Cambridge Polity Press.

Hdaytkhvah, S. (1377). Cultural invasion (1st ed.). Tehran: the deputy and the Ministry of Education.

Held, D., \& Macgrew, A. (2001). the global Transformation Reader. Cambridge: Polity Press.

Nye, A. M. (1390). Journal of Cultural Preservation, (3) the first year.

Nye, J. (1389). Soft Power (tools for success in international politics), translation cleric Mehdi Seyed Mohsen zolfaghari. Tehran University of Imam Sadeq (AS).

Nye, J. S. (2004). Soft Power. The means to success in world Politics, New York: Public affairs.

Organization of Islamic Revolution Cultural Documents. (1373). culture and cultural invasion, from the words of the leader (May) Tehran Islamic Revolution Cultural Documents Nations publication, printing.

Panvf, M., \& Perron, M. (1368). cultural anthropology, translated by Ali asghar Asgari monastery. Tehran Weiss Publishing, printing.

Peasant went on, S. J. (1390). Journal of Strategic Studies, (51).

Rafiee, J. (1373). Culture aggressive, productive culture, information dissemination, Vol 4.

Rvsk, J., \& the Warren. (1369). Introduction to Sociology, Translated by B prophetic and Ahmad Karimi (3rd ed.). Tehran, Wilcox Library.

Saddle, M. (1383). How the threats are, waiting period (Special Issue Jryan shnasy hypocrisy in religious rule).

Security Studies. (1387). national power threats, indicators and dimensions. Tehran: National Defense University Press, excellent printing.

Thereafter, M. (1389). The Islamic Republic of Iran's soft power (2nd ed.). Publisher: University of Imam sadeq (AS), Imam hossein University and the Institute of the prophet of Islam.

\section{Copyrights}

Copyright for this article is retained by the author(s), with first publication rights granted to the journal.

This is an open-access article distributed under the terms and conditions of the Creative Commons Attribution license (http://creativecommons.org/licenses/by/3.0/). 